\title{
THE DIFFERENCE OF HUMAN LEUKOCYTE ANTIGEN-E (HLA-E) EXPRESSION AND NATURAL KILLER CELLS (NK CELLS) IN TROPHOBLAST BETWEEN INTRAUTERINE GROWTH RESTRICTION (IUGR) AND NORMAL PREGNANCY
}

\author{
Sri Sulistyowati, Supriyadi Hari Respati, Soetrisno, Bambang Triono Cahyadi \\ Department of Obstetrics and Gynecology, Faculty of Medicine, Sebelas Maret University, Indonesia
}

Correspondence author:

\section{Soetrisno}

Department of Obstetrics and Gynecology, Faculty of Medicine, Sebelas Maret University, Indonesia Email: soetrisno spogk@yahoo.com

\author{
Article Info: \\ Received: 2 June 2017 \\ Revised: 25 March 2018 \\ Accepted: 30 April 2018 \\ Available online: 31 December \\ 2018 \\ Keywords: HLA-E, NK Cells, \\ IUGR, Normal Pregnancy \\ DOI: $10.20956 / n m s j . v 3 i 1.5781$
}

\begin{abstract}
Introduction: Intrauterine growth restriction (IUGR) is still a major cause of perinatal morbidity and mortality. Human Leukocyte Antigen - E and NK cells are thought to play an important role towards the process of IUGR. To determine etiopathogenesis of HLA-E expression and NK Cell in IUGR.

Methods: An analytical observational study conducted through a crosssectional approach. The research was conducted on March-October 2015 in Department of Obstetrics and Gynecology, Dr. Moewardi Hospital, Surakarta and Laboratory of Anatomical Pathology, Faculty of Medicine, Sebelas Maret University, Surakarta. In Subjects which consisted of 20 IUGR- and 20 normal pregnant-patients, the HLA-E expression and NK cells were examined in trophoblast using immunohistochemical method and statistical analysis using ttest.

Results: The average of HLA-E expression in the trophoblast from IUGR group were $17.80 \pm 5.55$, compared than in normal pregnancy were $66.23 \pm$ 19.83 , with $\mathrm{p}$ value $=0.0001(\mathrm{p}<0.05)$. The average of NK cells in trophoblast in IUGR group were $137.71 \pm 28.09$ compared than in normal pregnancy were $31.75 \pm 14.77$, with $\mathrm{p}$ value $=0.0001(\mathrm{p}<0.05)$.

Conclusion: HLA-E expression in normal pregnancy trophoblasts were higher than in pregnancies with IUGR. Expression of NK cells in pregnancy with IUGR were higher compared than in normal pregnancy.
\end{abstract}

\section{Pendahuluan}

Pertumbuhan Janin Terhambat (PJT) adalah suatu keadaan dimana berat badan janin dibawah 10 percentil untuk masa kehamilan atau kurang dari 2 standar deviasi di bawah rata-rata dari masa kehamilan. ${ }^{1}$ Prevalensi PJT di dunia adalah enam kali lebih tinggi di negara berkembang, $75 \%$ di antaranya berada di Asia, Afrika (20\%) dan Amerika latin (5\%). Di Indonesia, prevalensi rata-rata dari 4 pusat kesehatan ibu dan anak selama periode dari 2004 ke 2005 adalah 4,4\%, dengan prevalensi tertinggi $(6,44 \%)$ dilaporkan di RS Sardjito Yogyakarta 2,3 Salah satu teori utama mengenai penyebab terjadinya pertumbuhan janin terhambat yaitu hasil interaksi plasenta dengan sistem imun maternal, dimana selama kehamilan mengalami kontak langsung dengan fetus yang semi-alogenik. Sel jenis khusus yaitu trofoblas, berasal dari fetus, menginvasi uterus dan kontak langsung dengan sistem imun maternal. ${ }^{1}$ Salah 
satu yang berperan dalam proses toleransi imun maternal pada materno-feto interface adalah suatu antigen yang dikenal dengan Human Leukocyte Antigens/ HLA-E yang diduga memegang peranan penting pada proses implantasi dalam proses embryogenesis, diketahui mempunyai peranan dalam mengontrol invasi sel trofoblas dan mempertahankan kondisi imunotoleransi local. ${ }^{4}$ HLA-E secara spesifik berinteraksi dengan CD94/NKG2A mengakibatkan terjadinya ikatan antara phosphatase SHP-1 dengan phosphorylated tyrosine pada NKG2A sehingga terjadi inhibisi terhadap sel NK. Aktifitas imunomodulasi HLAE tersebut sangat bermanfaat pada keberhasilan kehamilan karena lebih dari $90 \%$ limfosit CD $56+$ pada desidua terkonstitusi oleh CD94/NKG2+ pada sel NK. Aktifitas regulasi tersebut menunjukkan peranan molekul HLA-E dalam melindungi janin dari sistem imun maternal pada kehamilan normal sekaligus mencegah terjadinya pertumbuhan janin terhambat. $^{5}$

Sel NK menghasilkan sitokin tipe I seperti TNF- $\alpha$ dan IFN- $\gamma$, yang memberikan efek negatif pada implantasi dan invasi trofoblas. TNF- $\alpha$ memberikan stimulasi apoptosis terhadap sel trofoblas dan IFN- $\gamma$ meningkatkan kemampuan sel sitokin tersebut. TNF- $\alpha$ dan IFN$\gamma$ juga dapat menghambat perkembangan fetus dengan cara mengaktivasi protrombinase sehingga dihasilkan trombin. Aktivasi trombin mengakibatkan terjadinya pembekuan darah dan pembentukan interleukin-8 yang akan menyebabkan sel endotelial untuk menghentikan aliran darah ke plasenta yang sedang berkembang. ${ }^{6,7}$ Penelitian ini bertujuan untuk mengetahui etiopatogenesis ekspresi HLA-E dan sel NK pada PJT
Penelitian dilaksanakan di Departemen Obstetri dan Ginekologi, RS.Dr. Moewardi, Surakarta mulai bulan Maret - Oktober 2015. Pemeriksaan ekspresi protein HLA-E dan Sel NK dengan metode immunohistokimia dilakukan di Laboratorium Patologi Anatomi, Fakultas Kedokteran Universitas Sebelas Maret (FKUNS), Surakarta. Jenis penelitian adalah observasional analitik dengan pendekatan cross sectional. Penelitian dilakukan pada kelompok ibu hamil dengan pertumbuhan janin terhambat dan ibu hamil normal untuk menganalisis ekspresi HLA-E dan sel NK trofoblas. Besar sampel untuk uji hipotesis ditentukan berdasarkan rumus Murti. ${ }^{8}$ Berdasarkan rumus tersebut, besar subyek untuk tiap kelompok adalah 20 orang. Dengan kriteria inklusi yaitu, usia ibu $20-35$ tahun, janin tunggal, hamil dengan pertumbuhan janin terhambat dan kehamilan normal, bersedia mengikuti penelitian. Kriteria eksklusi meliputi ibu hamil dengan diabetes mellitus, kelainan ginjal, kelainan hati, kelainan jantung dan hipertensi kronis, dan Ibu hamil dengan ketuban pecah dini dan infeksi intra uterin.

Pemeriksaan ekspresi HLA-E dan sel NK pada trofoblast dilakukan dengan menggunakan metode imunohistokimia dengan menggunakan antibodi HLA-E (3H2679): (Santa Cruz Biotechnology) dan anti-CD94 (HP-3B1): (Abcam). Intensitas warna dari setiap slide preparat biopsi diamati dengan perbesaran 400x pada 9 lapang pandang. Ekspresi HLA-E dan sel NK pada trofoblast dihitung berdasar intensitas ekspresinya, lalu dibuat persentasenya dengan jumlah sel keseluruhan. Nilai persentase yang didapatkan diubah menjadi angka dan dihitung sesuai rumus skor histologis. Semakin tinggi skor histologis, semakin kuat ekspresinya. ${ }^{9}$ Analisis data dilakukan dengan uji t menggunakan SPSS versi 17.00 for Windows

\section{METODE}

\section{HASIL}

Tabel 1. Karakteristik Subyek Penelitian

\begin{tabular}{llrrrr}
\hline Variabel & N & \multicolumn{1}{c}{ Min } & \multicolumn{1}{c}{ Max } & \multicolumn{1}{c}{ Rerata } & \multicolumn{1}{c}{ SD } \\
\hline Umur ibu (tahun) & 40 & 21,00 & 42,00 & 30,68 & 5,27 \\
Umur kehamilan (minggu) & 40 & 37,00 & 40,00 & 38,20 & 1,14 \\
Berat Bayi Lahir (gr) & 40 & 1900,00 & 3500,00 & 2656,25 & 536,75 \\
HLA-E & 40 & 6,82 & 120,50 & 42,02 & 28,42 \\
Sel NK & 40 & 11,28 & 194,72 & 84,73 & 58,05 \\
\hline
\end{tabular}


Dari table 1, didapatkan bahwa rerata umur ibu hamil adalah 30,68 $\pm 5,27$ tahun, umur kehamilan rerata $38,20 \pm 1,14$ minggu, berat badan bayi lahir rerata $2656,25 \pm 536,75$, ekspresi HLA-E rerata $42,02 \pm 28,42$, dan sel NK rerata $84,73 \pm 58,05$. Homogenitas dari data penelitian dan kontrol secara statistic diuji dengan One-Sample Kolmogorov-Smirnov Test, dan data menunjukan homogen ( $>00.05)$.

Tabel 2. Distribusi Rerata Ekspresi HLA-E pada kehamilan normal dan pertumbuhan janin terhambat

\begin{tabular}{lclc}
\hline Kelompok & Besar Sampel (N) & $\begin{array}{c}\text { Distribusi Rerata } \\
\text { Kadar HLA-E }\end{array}$ & $\mathrm{p}$ \\
\hline Normal & 20 & $66,23 \pm 19,83$ & $\left.0,0001^{*}\right)$ \\
PJT & 20 & $17,80 \pm 5,55$ & \\
\hline${ }^{8}$ Nilai signifikansi $\mathrm{p}<0.05$ & &
\end{tabular}

Dari tabel 2 terlihat bahwa distribusi rerata ekspresi HLA-E pada kehamilan normal 66,23 + 19,83, dan rerata ekspresi HLA-E pada kehamilan dengan pertumbuhan janin terhambat $17,80 \pm 5,55$. Terdapat perbedaan yang bermakna secara statistik antara ekspresi HLA-E pada kelompok kehamilan normal dan kelompok kehamilan PJT dengan nilai $p=0,0001(\mathrm{p}<0,05)$. Analisis variabel ekspresi HLA-E dengan menggunakan uji distribusi normal (Kolmogorov-Smirnov) pada kelompok kehamilan PJT dan kelompok kehamilan normal terdistribusi normal dengan nilai $\mathrm{p}=0,97(\mathrm{p}>0.05)$ untuk kelompok PJT dan $\mathrm{p}=0,98(\mathrm{p}>0.05)$ untuk kelompok normal.

Tabel 3 Distribusi Rerata Sel NK pada persalinan normal dan pertumbuhan janin terhambat

\begin{tabular}{lclc}
\hline Kelompok & Besar Sampel (N) & $\begin{array}{l}\text { Distribusi Rerata } \\
\text { Ekspresi Sel-NK }\end{array}$ & $\mathrm{p}$ \\
\hline Hamil Normal & 20 & $31,75 \pm 14,77$ & $\left.0,0001^{*}\right)$ \\
PJT & 20 & $137,71 \pm 28,09$ & \\
\hline
\end{tabular}

${ }^{8}$ Nilai signifikansi $\mathrm{p}<0.05$

Tabel 3 menjelaskan nilai rata-rata sel NK pada kelompok kehamilan normal sebesar $31,75 \pm 14,77$, sedangkan rerata sel NK pada kelompok kehamilan dengan pertumbuhan janin terhambat sebesar $137,71 \pm 28,09$ dan nilai $\mathrm{p}=$ $0.0001(<0.05)$ yang berarti membuktikan ada perbedaan bermakna antara nilai rerata sel NK kehamilan normal dengan kehamilan pertumbuhan janin terhambat. Analisis variabel ekspresi sel NK dengan menggunakan uji distribusi normal (Kolmogorov-Smirnov) pada kelompok kehamilan dengan pertumbuhan janin terhambat dan kelompok kehamilan normal, terdistribusi secara normal dengan nilai $\mathrm{p}=0.96$
( $p>0.05)$ untuk kehamilan dengan pertumbuhan janin terhambat dan $\mathrm{p}=0.93(\mathrm{p}>0.05)$ untuk kehamilan normal.

\section{PEMBAHASAN}

Implantasi fetoplasenta ke permukaan miometrium pada proses kehamilan membutuhkan beberapa elemen, yaitu toleransi imunologi antara fetoplasental dan maternal, pertumbuhan trofoblas yang akan melakukan invasi ke dalam lumen arteria spiralis dan pembentukan sistem pertahanan sistem imun. Komponen fetoplasental yang melakukan invasi 
ke miometrium melalui arteria spiralis secara imunologi akan menimbulkan dampak adaptasi atau maladaptasi yang sangat penting dalam proses kehamilan. Maladaptasi ini disebabkan karena fetoplasental mengandung lebih dari 50\% antigen paternal dari suami. Antigen paternal akan mengaktifkan HLA-E sehingga pada saat trofoblas invasi ke dalam sistem imun maternal akan menimbulkan suatu respon imunologis dari sisi maternal untuk membuat suatu antibodi sebagai suatu anti paternal cytotoxic antigen (APC antigen) yang seharusnya berfungsi untuk tidak menghancurkan kehamilan tersebut yang secara imunologis fetus dan trofoblas menjadi suatu semi allograft yang akan memberikan reaksi autoimune disease, sehingga terbentuk suatu maladaptasi imun antara fetoplasental dengan sisi maternal. ${ }^{5}$

Maladaptasi sistem imun maternal akan menyebabkan peningkatan aktivitas dari sel-sel lekosit sehingga akan mempengaruhi perkembangan fetoplasenta, invasi trofoblas ke dalam miometrium dan reaksi imunologi serta secara klinis akan menyebabkan pertumbuhan janin terhambat. ${ }^{10}$

Pada penelitian ini ekspresi HLA-E pada kelompok kehamilan normal menunjukkan rerata sebesar 66,23 dengan simpangan deviasi sebesar 19,83 $(66,23 \pm 19,83)$, sedangkan pada kelompok kehamilan dengan pertumbuhan janin terhambat menunjukkan rerata ekspresi HLA-E sebesar 17,80 dengan simpangan deviasi sebesar 5,55 $(17,80 \pm 5,55)$. Analisis uji t dengan menggunakan $\alpha=0.05$ membuktikan bahwa terdapat perbedaan yang signifikan dengan nilai $\mathrm{p}=0.0001 \quad(<0.05)$. Didapatkan ekspresi HLA-E yang rendah pada kelompok PJT dibandingkan kehamilan normal. Keadaan ini menunjukkan mungkin HLA-E berperan dalam toleransi imun semialogenik fetus oleh ibu. Kurangnya ekspresi HLA-E akan mengakibatkan terhambatnya invasi trofoblas terhadap arteri spiralis oleh aktivitas sitolisis sel NK desidua. Hambatan dari invasi trofoblas akan menyebabkan hipoksia plasenta yang salah satunya komplikasinya dapat mengakibatkan PJT. $^{5}$

Pemeriksaan imunohistokimia sel NK pada kelompok kehamilan normal menunjukkan rerata sebesar 31,75 dengan simpangan deviasi sebesar 14,77 $(31,75 \pm 14,77)$, sedangkan pada kelompok kehamilan dengan PJT menunjukkan rerata sel NK sebesar 137,71 dengan simpangan deviasi sebesar 28,09 $(137,71 \pm 28,09)$. Analisis uji t dengan menggunakan $\alpha=0.05$ membuktikan bahwa terdapat perbedaan yang signifikan dengan nilai $\mathrm{p}=0.0001(<0.05)$. Didapatkan sel NK yang tinggi pada kelompok PJT dibandingkan kehamilan normal. Sel NK yang berlebihan akan mengakibatkan produksi sitokin yaitu TNF- $\alpha$ dan IFN- $\gamma$ yang berlebihan sehingga invasi trofoblas ke desidua terhambat. ${ }^{6,7}$ Tanpa adanya invasi trofoblas yang tepat, maka arteri maternal tidak akan dibentuk ulang sehingga aliran utero plasenta menurun dan terjadi hipoksia/iskemia plasenta yang menyebabkan PJT. ${ }^{5}$

Sebuah penelitian sebelumnya, membandingkan kadar sel NK darah perifer pada wanita dengan PJT dengan wanita dengan kehamilan normal. Hasil penelitian menunjukkan rerata kadar sel NK pada PJT secara signifikan lebih tinggi. ${ }^{11}$ Penelitian lain terhadap mencit memberikan hasil bahwa sel NK berhubungan dengan berat lahir yang lebih rendah. ${ }^{12}$

Penelitian lainnya membandingkan kadar sitokin yang dihasilkan oleh sel NK yaitu TNF- $\alpha$ dan IFN- $\gamma$ antara kehamilan normal dan PJT. Hasil penelitian ini menunjukkan bahwa kadar TNF- $\alpha$ dan IFN- $\gamma$ pada PJT secara signifikan lebih tinggi dibandingkan dengan kehamilan normal. $^{7}$

Penelitian lain juga menunjukkan adanya ekspresi HLA-E pada plasenta kehamilan normal dan interaksinya dengan reseptor penghambat sel NK, yaitu CD94/NKG2A. ${ }^{13}$ Selanjutnya HLA-E akan mengadakan suatu kolaborasi dengan HLA-E untuk mencegah terjadinya sitotoksisitas. HLA-E merupakan suatu inhibitor dari sel NK pada feto maternal interface, tempat terjadi kontak langsung dengan sistem imun maternal. Selain itu ko-ekspresi dari HLA-E diperlukan dalam melakukan inhibisi sel NK pada uterus. ${ }^{6}$ HLA-E secara spesifik berinteraksi dengan CD94/NKG2A mengakibatkan terjadinya ikatan antara phosphatase SHP-1 dengan phosphorylated tyrosine pada NKG2A sehingga terjadi inhibisi terhadap sel NK. ${ }^{5}$

Aktifitas immunomodulasi tersebut sangat berguna dalam proses kehamilan karena lebih dari 90\% dari limfosit CD56+ pada desidua terdiri dari CD94/NKG2 + sel NK. ${ }^{14}$ Aktifitas regulasi tersebut menunjukkan peranan molekul HLA-E dalam melindungi janin dari sistem imun maternal pada kehamilan normal sekaligus mencegah terjadinya pertumbuhan janin terhambat. $^{5}$ 


\section{KESIMPULAN}

Sebagai kesimpulan, ekspresi HLA-E di trofoblas kehamilan normal lebih tinggi

\section{DAFTAR PUSTAKA}

1. Figueras, F., Gardosi, J. Intrauterine Growth Restriction: New Concepts in Antenatal Surveillance, Diagnosis, and Management. Am J Obstet Gynecol. 2011; 204(4): 288300 .

2. Himpunan Kedokteran Fetomaternal Indonesia. Panduan Penatalaksanaan Kasus Obstetri, Himpunan Kedokteran Fetomaternal Perkumpulan Obstetri dan Ginekologi Indonesia. Editor: Karkata M.K., Kristanto H. 2012; 5: 79-105.

3. Sumawan, H., Purwara, B.P., Krisnadi, S.R. Low Maternal Leptin Levels in Preeclamptic Women with Fetal Growth Restriction. Open J Obstet Gynecol. 2013; 3: 536-540

4. Eastabrook, G., Hu, Y., Dadelszen, P.V. The Role of Decidual Natural Killer Cells in Normal Placentation and in the Pathogenesis of Preeclampsia. J Obstet Gynaecol Can. 2008; 30(6): 467-476.

5. Tripathi, P., Naik, S., Agrawal, S. Role of HLA-G, HLA-E and KIR2DL4 in Pregnancy. Int J Hum Genet. 2007; 7(3): 219-233.

6. Nieuwenhoven, A.L.V., Heineman, M.J., Faas, M.M. The Immunology of Successful Pregnancy. Hum Reprod Update.. 2003; 9(4): 347-357.

7. Raghupathy, R., Al-Azemi, M., Azizieh, F. Intrauterine Growth Restriction: Cytokine Profiles of Trophoblast Antigen-Stimulated Maternal Lymphocytes. Clin Dev Immunol. 2012; 2012; 1-10.

8. Murti, B. Desain dan Ukuran Sampel untuk Penelitian Kuantitatif dan Kualitatif di dibandingkan kehamilan dengan PJT. Ekspresi sel NK pada kehamilan dengan PJT lebih tinggi dibandingkan dengan kehamilan normal.

Bidang Kesehatan. Gadjah Mada University Press, Yogyakarta. 2010.

9. Barut, F., Barut, A., Gun, B.D., Kandemir, N.O., Harma, M.I., Harma, M., et al. Intrauterine Growth Restriction and Placental Angiogenesis. Diagn Pathol. 2010; 5(24): 17.

10. Moffett, A., Colucci, F. Uterine NK Cells: Active Regulators at the Maternal-Fetal Interface. J Clin Invest. 2014. 124(5): 18721879.

11. Vesce, F., Cagnazzo, E., Giugliano, E., Mossuto, R., Marci, R. The Behaviour of the Peripheral Natural Killer Cells in the Foetal Growth Restriction. Eur Rev Med Pharmacol Sci. 2014; 18(16): 2248-2252.

12. Kieckbusch, J., Gaynor, L.M., Moffett, A., Colucci, F. MHC-dependent Inhibition of Uterine NK Cells Impedes Fetal Growth and Decidual Vascular Remodelling. Nat Comm. 2014; 5(3359): 1-12.

13. Bhalla, A., Stone, P.R., Liddell, H.S., Zanderigo, A., Chamley, L.W. Comparison of The Expression of Human Leukocyte Antigen (HLA)-G and HLA-E in Women with Normal Pregnancy and Those with Recurrent Miscarriage. Reproduction, 2006; 131(3): 583-589.

14. Mallia, J.V., Das, D.K., Maitra, A. Role of HLA in Human Pregnancy. Int J Hum Genet. 2012; 12(1): 33-36. 